\title{
Isu HAM dalam Kontestasi Pemilu 2014 Sebuah Pendekatan Framing dan Ideologi Media
}

\author{
Halimatusa'diah \\ Akademi Komunikasi Bina Sarana Informatika
}

\begin{abstract}
Research related to the problem of how the media frame the issue of human rights violations committed by the presidential candidate Prabowo Subianto and the background ideology behind the media presentation of the issue. This research aims to answer how vivanews.com mediaindonesia.com and framing the issues surrounding human rights violations perpetrated Prabowo Subianto. Theoritical thought that became the cornerstone of thought in this research is the theory of social construction of Berger and Luckmann with constructivist paradigm rests on a qualitative approach through method with framing analysis. The results showed how media owners (or vivanews.com mediaindonesia.com) blatantly use the media as a means of political campaigns. The influence of media owners against neutrality power news very perceptible. News coverage in both media is no longer offering a clarity of thought, let alone the discourse of the political education for the public, but also to "the Boxer" which is right behind the candidates. The transformation of media as social control, now become a boxer who inseparable from the affiliate owners of media on political parties.
\end{abstract}

Key Words : framing media, social construction theory, media ideology

\begin{abstract}
Abstrak
Penelitian terkait dengan permasalahan bagaimana media membingkai isu pelanggaran HAM yang dilakukan oleh calon presiden Prabowo Subianto dan latar belakang ideologi media di balik penyajian isu tersebut. Penelitian ini bertujuan untuk menjawab bagaimana vivanews.com dan mediaindonesia.com membingkai isu seputar pelanggaran HAM yang dilakukan Prabowo Subianto. Pemikiran teoritik yang menjadi landasan berpikir dalam penelitian ini adalah teori konstruksi sosial dari Berger dan Luckmann, dengan berpijak pada paradigma konstruktivis melalui pendekatan kualitatif dengan metode analisa pembingkaian (framing). Hasil penelitian menunjukkan bagaimana pemilik media (vivanews.com ataupun mediaindonesia.com) secara terang-terangan menggunakan media sebagai sarana kampanye politik. Pengaruh kekuasaan pemilik media terhadap netralitas berita sangat kentara. Pemberitaan di kedua media ini tidak lagi menawarkan wacana kejernihan berpikir, apalagi wahana pendidikan politik bagi publik, melainkan turut menjadi "petarung" yang berada persis di belakang para kandidat. Transformasi media yang semula sebagai kontrol sosial, kini menjadi petarung tidak terlepas dari afiliasi pemilik media terhadap partai politik.
\end{abstract}

Kata Kunci : framing media, teori konstruksi sosial, ideologi media 


\section{A. Pendahuluan}

Pemilu 2014 telah menghadirkan dan memperkenalkan beberapa hal baru bagi publik Indonesia. Hal ini tentunya merupakan indikasi positif tentang semakin berkualitasnya demokrasi di Indonesia. Meski tampak tidak mulus, tetapi anak-anak tangga inilah yang perlu dilewati agar Indonesia nantinya bisa menjadi negara yang mengadopsi demokrasi dengan bijak. Salah satu fenomena yang berkembang pada pemilihan Presiden 2014 ini adalah semakin pekanya publik terhadap isu-isu seputar kandidat Presiden dan Wakil Presiden, contohnya adalah penegakan HAM.

Isu pelanggaran HAM yang diduga dilakukan oleh capres Prabowo Subianto kini banyak menghiasi pemberitaan media massa. Sejak Sabtu, 7 Juni 2014, beredar surat rekomendasi pemecatan Prabowo Subianto di media sosial. Adalah Ulin Yusron, seorang penggiat dunia maya yang pertama mengunggah surat itu di akun twitter@ulinyusron. Dokumen itu di-retwett ribuan kali dan segera menghiasi pemberitaan media massa (http://indonesia-

baru.liputan6.com/read/2062435/suratrekomendasi-pemecatan-prabowoberedar\#sthash.MfsZ5kDk.dpuf， diakses pada 3 Juli 2014).

Sempat terjadi pro-kontra tentang kesahihan isi dokumen tersebut. Tudingan sebagai pelanggar HAM terhadap calon presiden Partai Gerindra Prabowo Subianto dalam kasus penculikan aktivis 1997-1998 tentunya mengancam elektabilitas Prabowo sebagai calon presiden. Isu HAM yang dimunculkan saat momentum pilpres ini tentunya sangat politis.

Survei yang dilakukan Lingkaran Survei Indonesia (LSI) menyimpulkan, $32,8 \%$ pemilih telah mendengar isu Prabowo terlibat dalam penculikan. LSI menyebut kasus penculikan tersebut dengan 'aktivis gate'. "Dengan hasil survei yang menunjukan kuatnya dampak 'aktivis gate' terhadap elektabilitas Prabowo, LSI memprediksi jika yang mendengar itu meluas lagi menjadi 50\%, apalagi 70\%, apalagi 90\%, itu akan menjadi lonceng kematian bagi elektabilitas Prabowo. LSI menyimpulkan, pada Juni 2014, 51,5\% publik percaya kalau Prabowo terlibat dalam kasus HAM 1997/1998. Hanya 37,6\% yang tidak percaya kalau Prabowo terlibat. Dampaknya adalah 56,8\% publik yang mendengar kasus keterlibatan Prabowo bakal mempertimbangkan niatnya dalam mendukung Prabowo. Hanya 34,3\% yang menyatakan tidak terpengaruh dan mantap memilih Prabowo. Isu HAM yang terus berhembus pascabocornya dokumen pemecatan Prabowo dari TNI atas rekomendasi Dewan Kehormatan Perwira (DKP) berpotensi menurunkan elektabilitas mantan Danjen Kopassus itu (http://www.beritasatu.com/nasional/190 271-kasus-penculikan-aktivis-ancamelektabilitas-prabowo.html, diakses pada 3 Juli 2014)

Banyak pihak menilai, ini merupakan black campaign yang ditujukan kepada capres Prabowo Subianto. Namun, tidak dapat dipungkiri, media massa berperan besar dalam pemberitaan kasus ini. Melalui mekanisme agendanya, Pers mengambil alih ruang publik dalam membentuk kesadaran massa. Dalam konteks ini, informasi politik terkait kontestasi antar partai politik maupun kandidat capres dan cawapres memiliki apa yang disebut sebagai "news value" bagi media. Memang, media massa menjadi jembatan paling efisien dan efektif bagi capres dan cawapres dalam menyampaikan visimisinya. Kehadiran media menjadi sangat penting mengingat rakyat yang nantinya akan "diayomi" oleh para kandidat ini juga punya hak untuk mengetahui program 
kerjanya kelak jika terpilih jadi presiden atau wakil presiden.

Masalah dalam penelitian terkait dengan bagaimana media membingkai isu pelanggaran HAM yang dilakukan oleh capres Prabowo Subianto dan latar belakang ideologi media di balik penyajian isu tersebut. Menarik dalam hal ini ketika media massa memberitakan isu seputar capres dan cawapres dalam konteks ini mengenai isu HAM, sementara pemiliknya dari media tersebut berafiliasi politik dengan salah satu kandidat caprers dan cawapres.Dalam hal ini menarik untuk meneliti pemberitaan mengenai isu ham capres-cawapres yang dimuat oleh portal berita mediaindonesia.com dan vivanews.com. Dipahami bersama bahwa vivanews dibawah kendali Abu Rizal Bakrie yang jelas mendukung caprescawapres Parabowo-Hatta. Sedangkan mediaindonesia.com secara nyata berada dibelakang pasangan capres-cawapres nomor dua yakni Jokowi-JK.

Penelitian ini bertujuan untuk menjawab bagaimana vivanews.com dan mediaindonesia.com membingkai isu seputar pelanggaran HAM yang dilakukan Prabowo Subianto. Dalam hal ini dibatasi pada pemberitaan yang dilakukan oleh vivanews.com dan mediaindonesia.com pada periode 19-24 Juni 2014. Selain itu, juga dimaksudkan untuk menjelaskan ideologi media di balik pembingkaian isu tersebut.

Analisis framing merupakan metode untuk melihat cara bercerita (story telling) media atas peristiwa. Cara bercerita itulah yang tergambar pada "cara melihat" terhadap realitas yang dijadikan berita. Cara ini berpengaruh pada hasil akhir konstruksi realitas (dalam Eriyanto, 2005). Dapat dikatakan bahwa seorang wartawan dalam sebuah media akan mengemas peristiwa sesuai dengan cara pandang media tersebut. Sehingga dari cara pandang sebuah media kemudian akan mempengaruhi cara bercerita seorang wartawan.

Salah satu pemikiran teoritik yang menjadi landasan berpikir dalam penelitian ini adalah teori konstruksi sosial (social construction) dari Berger dan Luckmann (dalam Littlejohn, 2008: 67). Berger dan Luckman mengatakan institusi masyarakat tercipta dan dipertahankan atau diubah melalui tindakan dan interaksi manusia. Meskipun masyarakat dan institusi sosial terlihat nyata secara obyektif, namun pada kenyataan semuanya dibangun dalam definisi subjektif melalui proses interaksi. Objektivitas baru bisa terjadi melalui penegasan berulang-ulang yang diberikan oleh orang lain yang memiliki definisi subyektif yang sama. Pada tingkat generalitas yang paling tinggi, manusia menciptakan dunia dalam makna simbolis yang universal, yaitu pandangan hidupnya yang menyeluruh, yang memberi legitimasi dan mengatur bentuk-bentuk sosial serta memberi makna pada berbagai bidang kehidupannya.

Terkait dengan bingkai media, Norris, Kern dan Just (2003) menyatakan, the essence of framing is selection to prioritize some facts, images, or developments over others, thereby unconsciously promoting one particular interpretation of events. Membuat frame adalah menyeleksi beberapa aspek dari suatu pemahaman atas realitas dan membuatnya lebih menonjol dalam suatu teks yan dikomunikasikan sedemikian rupa hingga mempromosikan sebuah definisi permasalahan yang khusus, interpretasi kausal, evaluasi moral dan merekomendasi penanganannya (dalam Entman, 1993).

Framing secara esensial, menurut Robert M. Entman meliputi penyeleksian dan penonjolan, fungsi frame adalah mendefinisikan masalah, mendiagnosis penyebab, memberikan penilaian moral 
dan menawarkan penyelesaian masalah dengan tujuan memberi penekanan tertentu terhadap apa yang diwacanakan. Definisi lain tentang framing dikemukakan oleh Gamson dan Modigliani. Mereka berpendapat bahwa frame adalah cara bercerita yang menghadirkan konstruksi makna atas peristiwa-peristiwa yang berkaitan dengan objek suatu wacana (Gamson dan Modigliani, 1989: 3).

Gamson dan Modigliani mengandaikan wacana media terdiri dari sejumlah package interpretif yang mengandung konstruksi makna tentang objek wacana. Package adalah gugusan ide-ide yang memberi petunjuk mengenai isu apa yang dibicarakan dan peristiwa mana yang relevan dengan wacana yang terbentuk. Package adalah semacam skema atau struktur pemahaman yang digunakan individu untuk memaknai pesan yang disampaikan serta untuk menafsirkan pesan yang ia terima. Package tersebut dibayangkan sebagai struktur data yang mengorganisir sejumlah informasi sehingga dapat mengindikasikan posisi atau kecendrungan politik dan yang membantu komunikator untuk menjelaskan maknamakna di balik isu atau peristiwa yang sedang dibicarakan. Keberadaan package dalam suatu wacana berita ditunjukkan oleh keberadaan ide yang didukung oleh perangkat wacana seperti metaphor, depiction, catchphrase, exemplars dan visual image. Semuanya mengarah pada ide atau pandangan tertentu, masing masing kelompok berusaha menarik dukungan publik. Dengan mempertajam kemasan (package) tertentu dari sebuah isu politik, mereka dapat mengklaim bahwa opini publik yang berkembang mendukung kepentingan mereka, atau sesuai dengan kebenaran versi mereka.

Pan dan Kosicki (1991: 5-7) menyatakan framing dapat dipelajari sebagai suatu strategi untuk memproses dan mengkonstruksi wacana berita atau sebagai karakteristik wacana itu sendiri. Proses framing berkaitan erat dengan rutinitas dan konvensi profesional jurnalistik. Proses framing tidak dapat dipisahkan dari strategi pengolahan dan penyajian informasi dalam presentasi media. Dengan kata lain, proses framing merupakan bagian integral dari proses redaksional media massa. Dominasi sebuah frame dalam wacana berita bagaimanapun berkaitan dengan proses produksi berita yang melibatkan unsurunsur seperti reporter, redaktur dan lainlain.

Dalam konteks ini, seperti dijelaskan oleh Gamson, pekerja media menuangkan gagasannya, menggunakan gaya bahasanya sendiri serta memfrase dan mengutip sumber berita tertentu. Di saat yang sama, mereka membuat retorika - retorika yang menyiratkan keberpihakan dan kecenderungan tertentu (Gamson dan Modigliani, 1989:3).

$\begin{array}{ccc}\text { Keberadaan } & \text { berita maupun } \\ \text { bingkai yang digunakan } & \text { dalam }\end{array}$ pemberitaan tidak terlepas dari ideologi tertentu. Tegasnya, media dipengaruhi oleh ideologi tertentu. Hal ini tampak dari pendapat Hackett (dalam Tankard, 2001: 96) yang menyatakan, researchers should shift their approach from the study of objectivity and bias to the study of ideology in the news. The concept of ideology trancends the concept of bias. Ideology provides a framework through which the news media often present event. The concept of framing is one useful approach because it has the potential of getting beneath the surface of news coverage and exposing the hidden assumptions.

Dalam masyarakat modern, media merupakan situs produksi, reproduksi dan transformasi ideologi-ideologi. Ideologi bekerja dibanyak tempat dan tidak hanya 
di kepala saja. Institusi semacam media merupakan tempat sentral khusus karena media, dengan merujuk pada terminologinya, merupakan bagian dari alat-alat dominan untuk produksi ideologi. Apa yang "diproduksi" media adalah representasi-representasi mengenai dunia sosial, citra, deskripsi, eksplanasi dan bingkai untuk memahami bagaimana dunia ini dan mengapa dunia ini bekerja sebagaimana dikatakan dan ditunjukkan (Hall dalam Dinez dan Humes, 2003: 89).

Terkait dengan tema penelitian ini, sebelumnya telah ada penelitian mengenai analisis framing dalam pemberitaan di media massa, diantaranya yang dilakukan oleh Marliana Ngatmin pada tahun 2007 yakni yang berjudul "Analisa Framing Kasus Poligami KH. Abdullah Gymnastiar di media Kompas dan Republika. Hasil dari penelitian ini, Kompas melihat kasus ini sebagai masalah sosial islam sementara Republika melihatnya berdasar hukum islam.

Selanjutnya penelitian yang dilakukan oleh Karman pada 2012 yang berjudul "Analisis Framing Terhadap Pemberitaan Koran Tempo Mengenai Kasus Ledakan Bom di Masjid Mapolres Cirebon". Hasil penelitian ini mengungkapkan bahwa Tempo koran Tempo mengedepankan sumber dari pihak kepolisian, dan BNPT sebagai sudut pandangnya dalam melihat persoalan ini. Hal ini nampak dari teras beritanya. Judul headlinenya pun merupakan cerminan dari narasumbernya.

\section{B. Metodologi Penelitian}

Dalam tataran konseptual-teoritik, penelitian ini berpijak pada paradigma konstruktivis melalui pendekatan kualitatif dengan metode analisa pembingkaian (framing). Dalam penjelasan Hidayat (1999:39), ontologi paradigmanstruktivis memandang realitas sebagai konstruksi sosial yang diciptakan oleh individu. Namun demikian, kebenaran suatu realitas sosial bersifat nisbi, yang berlaku sesuai konteks spesifik yang dinilai relevan oleh pelaku sosial.

Realitas kehidupan sosial dipandang oleh paradigma ini bukanlah realitas yang netral tapi hasil dari konstruksi. Permasalahan yang telah diuraikan sebelumnya akan terjawab melalui pendekatan kualitatif dengan pisau analisis bingkai (analysis framing) model Gamson dan Modigliani. Subyek penelitian adalah dua buah berita tentang isu penculikan Aktivis yang dilakukan oleh capres Prabowo yang dimuat pada portal berita vivanews.com dan mediaindonesia.com selama satu pekan yakni pada periode 19 - 26 Juni 2014. Meski tidak setiap hari kedua media ini memberitakan tentang isu HAM terkait capres dan cawapres namun diasumsikan kurun waktu satu pekan mampu menjunjung aspek validitas hasil penelitian.

Analisis data dilakukan dengan menggunakan unsur-unsur analisis sebagaimana dimaksudkan dalam model Gamson dan Modigliani (Tankard, 2001: 97). Unsur itu berupa analisis kemasan media (media package) untuk menemukan bingkai inti (core frame) melalui analisis perangkat bingkai (framing devices) dan analisis perangkat penalaran (reasoning devices).

Analisis perangkat bingkai (framing devices) meliputi analisis metafora (metaphora), contoh (exemplars), gambaran (depictions), frasa mudah ditangkap (catchphrases), dan citra visual (visual image). Analisis perangkat penalaran (reasoning devices) meliputi analisis kausalitas (roots) dan analisis normatif pendukung bingkai (appeal to principle). 


\section{Hasil Penelitian}

Pemberitaan terkait dengan isu pelanggaran HAM yang disajikan mediaindonesia.com pada Jumat 19 Juni 2014 yang berjudul "Prabowo Inisiator Penculikan". Jika dikembalikan kepada dua isu sentral, jelaslah bahwa ini upaya menjatuhkan capres Prabowo. Sementara vivanews.com pada tanggal yang sama memuat berita dengan judul "Pemberhentian Prabowo Tak Terkait Kasus Penculikan". Untuk berita yang ini vivanews.com terlihat melakukan usaha memberikan "pertahanan" akan berita yang disajikan mediaindonesia.com kepada Prabowo atas masalah penculikan.

Visual image yang digunakan oleh mediaindonesia.com pada berita ini merupakan sosok Wiranto yang diambil dari low angle (sudut arah bawah). Ketika dalam posisi pengambilan gambar kamera diletakan lebih rendah dari subjek/objek maka gambar berasa lebih besar, berwibawa, percaya diri, memiliki kekuasaan (Halls, 2012:62). Ini sengaja dilakukan oleh media indonesia.com untuk membuat kesan Wiranto adalah sosok yang punya kekuasaan hal ini bisa diartikan punya kredibilitas dan kompetensi untuk menjelaskan kasus penculikan. Sedangkan visual image yang digunakan vivanews.com pada beritanya ialah gambar Prabowo dan Wiranto yang saling berpegangan tangan di depan masyarakat banyak. Sebetulnya redaksi ingin menekankan persahabatan dua mantan Jenderal kepada masyarakat.

Mediaindonesia.com melakukan framing catchphrases dengan membuat judul Prabowo Inisitor Penculikan. Judul berita bagaikan etalase pada toko yang menarik perhatian publik. Melalui judul ini pula publik yang tidak sempat membaca tubuh berita sudah merasa memahami isi beritanya. Inilah yang dimanfaatkan redaksi dengan menonjolkan kata 'inisiator' yang bermakna bahwa dalang penculikan adalah Prabowo. Bila ditelaah dengan seksama tentu akan memunculkan pertanyaan: mengapa baru momen Pilpres sekarang mediaindonesia.com mengangkat isu ini? Padahal dalam kajian jurnalistik ada konsep pemberitaan yang dikenal dengan istilah "kelanjutan berita" yang bisa digunakan untuk memberitakan persoalan sampai kasus tersebut benarbenar selesai. Harusnya sejak Prabowo diberhentikan dan pergi ke Jordania meninggalkan RI, mediaindonesia.com konsisten untuk memberitakannya. Ini berbeda sekali dengan judul dan sub judul yang dibuat oleh vivanews.com. Redaksi melakukan appeals to principle atau klaim moral Tim: Pemberhentian Prabowo Tak Terkait Kasus Penculikan. Lalu diikuti langsung pada sub judul dengan gunakan framing exemplar Bahkan Prabowo diberhentikan secara hormat. Tetap terima pensiun.

Dari hasil analisis model pembingkaian berita dari Gamson dan Modigliani ditemukan bahwa kedua media mempunyai beberapa tekanan berbeda. Meskipun sama-sama memberitakan tentang isu pelanggran HAM yang mengarah pada capres nomor satu namun dalam data yang dikutip, vivanews.com menekankan pada pembelaan atas sentimen negatif tentang pelanggaran HAM yang menuju pada Prabowo. Sedang mediaindonesia.com lebih menekankan pada sentimen negatif pada Prabowo Subianto. Hal ini terlihat dalam berita yang terdapat pada mediaindonesianews.com dan vivanews.com pada edisi 20 Juni-26 Juni 2014 yang dirinci dalam tabel berikut: 
Tabel 1. Temuan 19 Juni 2014

\begin{tabular}{|c|c|c|c|c|}
\hline \multirow[b]{2}{*}{ No } & \multirow{2}{*}{$\begin{array}{l}\text { Anatomi } \\
\text { Tubuh } \\
\text { berita }\end{array}$} & \multicolumn{2}{|c|}{ Media } & \multirow{2}{*}{$\begin{array}{l}\text { Analisa Framing model } \\
\text { Gamson dan Modigliani }\end{array}$} \\
\hline & & mediaindonesia.com & vivanews.com & \\
\hline 1 & Judul & 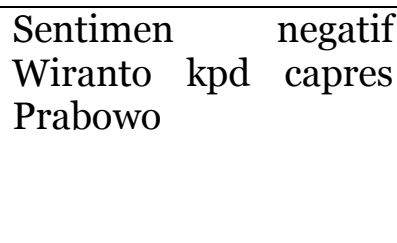 & $\begin{array}{l}\text { Membela capres } \\
\text { Prabowo }\end{array}$ & $\begin{array}{l}\text { Mediaindonesia.com: } \\
\text { melakukan appeals to } \\
\text { principle } \\
\text { Vivanes.com: melakukan } \\
\text { appeals to principle }\end{array}$ \\
\hline 2 & Foto & $\begin{array}{lr}\text { Membuat } & \text { sosok } \\
\text { Wiranto } & \text { lebih } \\
\text { berkompeten-kredibel }\end{array}$ & $\begin{array}{l}\text { Condong } \\
\text { bersifat netral }\end{array}$ & $\begin{array}{l}\text { Mediaindonesia.com: } \\
\text { melakukan appeals to } \\
\text { principle } \\
\text { Vivanes.com: melakukan } \\
\text { appeals to principle }\end{array}$ \\
\hline 3 & Lead (prg I) & 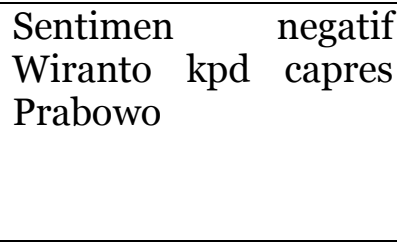 & $\begin{array}{l}\text { Membela capres } \\
\text { Prabowo }\end{array}$ & $\begin{array}{l}\text { Mediaindonesia.com: } \\
\text { melakukan appeals to } \\
\text { principle } \\
\text { Vivanes.com: melakukan } \\
\text { appeals to principle }\end{array}$ \\
\hline 4 & $\begin{array}{l}\text { tubuh berita } \\
\text { (prg II) }\end{array}$ & 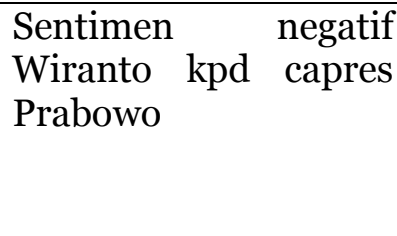 & $\begin{array}{l}\text { Membela capres } \\
\text { Prabowo }\end{array}$ & $\begin{array}{l}\text { Mediaindonesia.com: } \\
\text { melakukan appeals to } \\
\text { principle } \\
\text { Vivanes.com: melakukan } \\
\text { appeals to principle }\end{array}$ \\
\hline 5 & $\begin{array}{l}\text { tubuh berita } \\
\text { (prg III) }\end{array}$ & 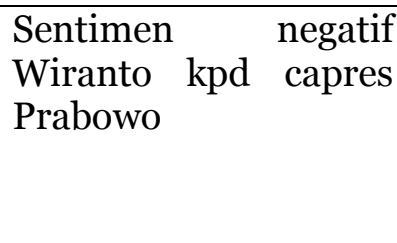 & $\begin{array}{l}\text { Membela capres } \\
\text { Prabowo }\end{array}$ & $\begin{array}{l}\text { Mediaindonesia.com: } \\
\text { melakukan appeals to } \\
\text { principle } \\
\text { Vivanes.com: melakukan } \\
\text { appeals to principle }\end{array}$ \\
\hline 6 & $\begin{array}{l}\text { tubuh berita } \\
\text { (prg IV) }\end{array}$ & $\begin{array}{ll}\text { Sentimen } & \text { negatif } \\
\text { Wiranto kpd } & \text { capres } \\
\text { Prabowo } & \end{array}$ & $\begin{array}{l}\text { Membela capres } \\
\text { Prabowo }\end{array}$ & $\begin{array}{l}\text { Mediaindonesia.com: } \\
\text { melakukan appeals to } \\
\text { principle } \\
\text { Vivanes.com: melakukan } \\
\text { appeals to principle }\end{array}$ \\
\hline 7 & $\begin{array}{l}\text { tubuh berita } \\
\text { (prg V) }\end{array}$ & $\begin{array}{ll}\text { Sentimen } & \text { negatif } \\
\text { Wiranto kpd } & \text { capres } \\
\text { Prabowo } & \end{array}$ & $\begin{array}{l}\text { Membela capres } \\
\text { Prabowo }\end{array}$ & $\begin{array}{l}\text { Mediaindonesia.com: } \\
\text { melakukan appeals to } \\
\text { principle } \\
\text { Vivanes.com: melakukan } \\
\text { appeals to principle }\end{array}$ \\
\hline 8 & $\begin{array}{l}\text { tubuh berita } \\
\text { (prg VI) }\end{array}$ & $\begin{array}{ll}\text { Sentimen } & \text { negatif } \\
\text { Wiranto kpd } & \text { capres } \\
\text { Prabowo } & \end{array}$ & $\begin{array}{l}\text { Membela capres } \\
\text { Prabowo }\end{array}$ & $\begin{array}{l}\text { Mediaindonesia.com: } \\
\text { melakukan appeals to } \\
\text { principle } \\
\text { Vivanes.com: melakukan } \\
\text { appeals to principle }\end{array}$ \\
\hline 9 & $\begin{array}{l}\text { tubuh berita } \\
\text { (prg VII) }\end{array}$ & $\begin{array}{ll}\text { Sentimen } & \text { negatif } \\
\text { Wiranto kpd } \\
\text { Prabowo }\end{array}$ & & $\begin{array}{l}\text { Mediaindonesia.com: } \\
\text { melakukan appeals } \\
\text { principle }\end{array}$ \\
\hline
\end{tabular}




\begin{tabular}{|c|c|l|l|ll|}
\hline 10 & $\begin{array}{c}\text { tubuh berita } \\
\text { (prg VIII) }\end{array}$ & $\begin{array}{l}\text { Sentimen negatif } \\
\text { Wiranto kpd capres } \\
\text { Prabowo }\end{array}$ & $\begin{array}{ll}\text { Mediaindonesia.com: } \\
\text { melakukan appeals to } \\
\text { principle }\end{array}$ \\
\hline 11 & $\begin{array}{c}\text { tubuh berita } \\
\text { (prg IX) }\end{array}$ & $\begin{array}{l}\text { Sentimen } \\
\text { Wiranto kpd capres } \\
\text { Prabowo }\end{array}$ & $\begin{array}{l}\text { Mediaindonesia.com: } \\
\text { melakukan appeals to } \\
\text { principle }\end{array}$ \\
\hline 12 & $\begin{array}{c}\text { tubuh berita } \\
\text { (prg X) }\end{array}$ & $\begin{array}{l}\text { Sentimen negatif } \\
\text { Wiranto kpd capres } \\
\text { Prabowo }\end{array}$ & $\begin{array}{l}\text { Mediaindonesia.com: } \\
\text { melakukan appeals to } \\
\text { principle }\end{array}$ \\
\hline
\end{tabular}

Hasil konstruksi penulis

Tabel 2. Temuan 20 Juni 2014 .

\begin{tabular}{|c|c|c|c|c|}
\hline \multirow{2}{*}{ No } & \multirow{2}{*}{$\begin{array}{c}\text { Anatomi } \\
\text { Tubuh berita }\end{array}$} & \multicolumn{2}{|c|}{ Media } & \multirow{2}{*}{$\begin{array}{l}\text { Analisa Framing model } \\
\text { Gamson dan Modiglian }\end{array}$} \\
\hline & & mediaindonesia.com & vivanews.com & \\
\hline 1 & Judul & $\begin{array}{l}\text { Menyudutkan } \\
\text { prabowo dgn isu } \\
\text { HAM }\end{array}$ & $\begin{array}{l}\text { Membela } \\
\text { capres dgn } \\
\text { mengcounter } \\
\text { isu HAM } \\
\text { Prabowo }\end{array}$ & $\begin{array}{l}\text { Mediaindonesia.com: } \\
\text { melakukan appeals to } \\
\text { principle } \\
\text { Vivanes.com: melakukan } \\
\text { appeals to principle }\end{array}$ \\
\hline 2 & Foto & - & - & \\
\hline 3 & Lead (prg I) & $\begin{array}{l}\text { Kampanye } \\
\text { Jokowi }\end{array}$ & $\begin{array}{l}\text { Membela } \\
\text { capres dgn } \\
\text { mengcounter } \\
\text { isu HAM } \\
\text { Prabowo }\end{array}$ & $\begin{array}{l}\text { Mediaindonesia.com: } \\
\text { melakukan appeals to } \\
\text { principle } \\
\text { Vivanes.com: melakukan } \\
\text { appeals to principle }\end{array}$ \\
\hline 4 & $\begin{array}{l}\text { tubuh berita } \\
\text { (prg II) }\end{array}$ & Kampanye jokowi & $\begin{array}{l}\text { Membela } \\
\text { capres dgn } \\
\text { mengcounter } \\
\text { isu HAM } \\
\text { Prabowo }\end{array}$ & $\begin{array}{l}\text { Mediaindonesia.com: } \\
\text { melakukan appeals to } \\
\text { principle } \\
\text { Vivanes.com: melakukan } \\
\text { appeals to principle }\end{array}$ \\
\hline 5 & $\begin{array}{l}\text { tubuh berita } \\
\text { (prg III) }\end{array}$ & $\begin{array}{l}\text { Mendeskreditkan } \\
\text { capres Prabowo }\end{array}$ & $\begin{array}{l}\text { Membela } \\
\text { capres dgn } \\
\text { mengcounter } \\
\text { isu HAM } \\
\text { Prabowo }\end{array}$ & $\begin{array}{l}\text { Mediaindonesia.com: } \\
\text { melakukan appeals to } \\
\text { principle } \\
\text { Vivanes.com: melakukan } \\
\text { appeals to principle }\end{array}$ \\
\hline
\end{tabular}

Hasil konstruksi penulis 
Tabel 3. Temuan 24 Juni 2014.

\begin{tabular}{|c|c|c|c|c|}
\hline \multirow[b]{2}{*}{ No } & \multirow{2}{*}{$\begin{array}{l}\text { Anatomi } \\
\text { Tubuh } \\
\text { berita }\end{array}$} & \multicolumn{2}{|c|}{ Media } & \multirow{2}{*}{$\begin{array}{l}\text { Analisa Framing model } \\
\text { Gamson dan Modigliani }\end{array}$} \\
\hline & & mediaindonesia.com & vivanews.com & \\
\hline \multirow{2}{*}{1} & \multirow{2}{*}{ Judul } & \multirow[t]{2}{*}{$\begin{array}{l}\text { Mendeskreditkan } \\
\text { capres Prabowo }\end{array}$} & \multirow{2}{*}{$\begin{array}{l}\text { Membela capres } \\
\text { dgn } \\
\text { mengcounter isu } \\
\text { HAM Prabowo }\end{array}$} & $\begin{array}{l}\text { Mediaindonesia.com : melakukan } \\
\text { appeals to principle }\end{array}$ \\
\hline & & & & $\begin{array}{l}\text { Vivanes.com: melakukan appeals } \\
\text { to principle }\end{array}$ \\
\hline 2 & Foto & - & - & - \\
\hline \multirow{2}{*}{3} & \multirow{2}{*}{ Lead (prg I) } & \multirow[t]{2}{*}{$\begin{array}{l}\text { Mendeskreditkan } \\
\text { capres Prabowo }\end{array}$} & \multirow{2}{*}{$\begin{array}{l}\text { Membela capres } \\
\text { dgn } \\
\text { mengcounter isu } \\
\text { HAM Prabowo }\end{array}$} & $\begin{array}{l}\text { Mediaindonesia.com : melakukan } \\
\text { appeals to principle }\end{array}$ \\
\hline & & & & $\begin{array}{l}\text { Vivanes.com: melakukan appeals } \\
\text { to principle }\end{array}$ \\
\hline \multirow{2}{*}{4} & \multirow{2}{*}{$\begin{array}{l}\text { tubuh berita } \\
\quad \text { (prg II) }\end{array}$} & \multirow[t]{2}{*}{$\begin{array}{l}\text { Mendeskreditkan } \\
\text { capres Prabowo }\end{array}$} & \multirow{2}{*}{$\begin{array}{l}\text { Membela capres } \\
\text { dgn } \\
\text { mengcounter isu } \\
\text { HAM Prabowo }\end{array}$} & $\begin{array}{l}\text { Mediaindonesia.com : melakukan } \\
\text { appeals to principle }\end{array}$ \\
\hline & & & & $\begin{array}{l}\text { Vivanes.com: melakukan appeals } \\
\text { to principle }\end{array}$ \\
\hline \multirow{2}{*}{5} & \multirow{2}{*}{$\begin{array}{l}\text { tubuh berita } \\
\quad(\text { prg III) }\end{array}$} & \multirow[t]{2}{*}{$\begin{array}{l}\text { Mendeskreditkan } \\
\text { capres Prabowo }\end{array}$} & \multirow{2}{*}{$\begin{array}{l}\text { Membela capres } \\
\text { dgn } \\
\text { mengcounter isu } \\
\text { HAM Prabowo }\end{array}$} & $\begin{array}{l}\text { Mediaindonesia.com : melakukan } \\
\text { appeals to principle }\end{array}$ \\
\hline & & & & $\begin{array}{l}\text { Vivanes.com: melakukan appeals } \\
\text { to principle }\end{array}$ \\
\hline \multirow{2}{*}{6} & \multirow{2}{*}{$\begin{array}{l}\text { tubuh berita } \\
\quad(\text { prg IV) }\end{array}$} & \multirow[t]{2}{*}{$\begin{array}{l}\text { Mendeskreditkan } \\
\text { capres Prabowo }\end{array}$} & \multirow{2}{*}{$\begin{array}{l}\text { Membela capres } \\
\text { dgn } \\
\text { mengcounter isu } \\
\text { HAM Prabowo }\end{array}$} & $\begin{array}{l}\text { Mediaindonesia.com : melakukan } \\
\text { appeals to principle }\end{array}$ \\
\hline & & & & $\begin{array}{l}\text { Vivanes.com: melakukan appeals } \\
\text { to principle }\end{array}$ \\
\hline 7 & $\begin{array}{l}\text { tubuh berita } \\
\quad(\operatorname{prg} \mathrm{V})\end{array}$ & $\begin{array}{l}\text { Mendeskreditkan } \\
\text { capres Prabowo }\end{array}$ & & $\begin{array}{l}\text { Mediaindonesia.com : melakukan } \\
\text { appeals to principle }\end{array}$ \\
\hline
\end{tabular}

Hasil konstruksi penulis

Dalam proses pemilihan fakta berdasarkan pada asumsi, wartawan dalam hal ini redaksi tidak mungkin memandang sebuah peristiwa tanpa perspektif (Eriyanto, 2002: 70). Dalam memilih fakta tersebut selalu terkandung dua kemungkinan yakni apa yang dipilih (included) dan apa yang harus dibuang (exluded). Redaksi akan selalu dihadapi pada persoalan hal yang perlu ditekankan pada sebuah berita, bagian mana dari sebuah realitas yang diberitakan serta bagian mana yang tidak diberitakan. Lalu memilih penekanan pada aspek dengan angle tertentu, mengedepankan salah satu fakta dan meniadakan fakta yang lain, sehingga terjadi sebuah pemahaman dan konstruksi atas sebuah peristiwa. Itulah sebabnya dalam tiap media akan berbeda pemberitaanya satu sama lain meski persoalan cenderung relatif sama.

\section{d. Pembahasan}

Dari hasil temuan jelas bahwa dalam menyuguhkan beritanya, media massa melakukan konstruksi terhadap simbol yang digunakan untuk memberikan referensi terhadap opini publik. Pemilihan kata dan penyuguhan foto yang digunakan sebagai representasi peristiwa yang dibuatnya berdasar makna yang terlebih dahulu menjadi kebijakan dari redaksi itu sendiri. John Thompson dalam Shoemaker dan Reese (1996: 128), Simbol yang dipakai media dalam hal ini 
kata yang dipilih media dibawah kekuasaan kuasa.

Selama ini vivanews.com dan mediaindonesia.com berusaha untuk mengkonstruksikan realitas, termasuk peristiwa-peristiwa yang ada kaitanya dengan capres-cawapres. Kedua redaksi ini menyusun berbagai fakta yang dikumpulkan ke dalam satu bentuk laporan jurnalistik, sebenarnya sampai batasan ini tidak berlebihan mengkonstruksinya. Namun karena isi beritanya menyerang capres lawan, pencitraan, kampanye inilah yang membuat "pabrik konstruksi" menjadi "petarung" dan mengesampingkan tanggung jawab serta kontrol sosialnya.

Dari temuan data dengan analisa framing model model Gamson dan Modigliani yang telah dilakukan, maka tidak diragukan bahwa keberpihakan kedua portal berita, yakni vivanews.com dan mediaindonesianews.com kepada capres-cawapres yang didukungnya tidak dapat dipungkiri lagi. Hampir sebagian besar prinsip yang digunakan kedua media massa tersebut appeals to principle yakni memberitakan berdasarkan klaim dari pihak media atau narasumber yang sengaja dipilih oleh redaksi. Jelaslah bahwa Vivanews.com cenderung berpihak pada kepada capres-cawapres PrabowoHatta. Sedang mediaindonesia.com dibawah bendera Media Group yang mendukung pasangan Jokowi-JK pemberitaan cenderung menyudutkan lawan politiknya. Kedua media tersebut melakukan konstruksi sehubungan dengan pemberitaan mengenai Prabowo terkait dengan isu pelanggaran HAM .

Sebagaimana yang diutarakan Sobur (2009: 162), bahwa dalam perspektif komunikasi, analisis framing dipakai untuk membedah cara-cara atau ideologi media saat mengkonstruksi fakta. Di dalam proses penseleksian realitas yang akan diberitakan oleh media, terdapat cara pandang atau perspektif yang mempengaruhinya. Perspektif tersebut kemudian yang mempengaruhi sebuah media dalam menentukan fakta yang diambil, bagian mana yang ditonjolkan atau dihilangkan dan akan dibawa ke mana berita tersebut. Framing adalah pendekatan yang digunakan untuk mengetahui cara pandang atau perspektif dari media tersebut.

Bila mengacu pada pemahaman di atas maka, dalam konteks ini baik kubu vivanews.com ataupun mediaindonesia.com dengan sengaja mengkonstruk berita yang sifatnya mendukung capres dan cawapres jagoan mereka. Hal ini tentu sesuai dengan cara pandang media terhadap capres dan cawapres yang dibelanya atas dasar kepentingan politik si pemilik media tersebut. Bukan atas dasar isu HAM yang diketengahkan. Isu HAM hanya sebagai peluru untuk menembak musuh politik atapun membela kandidat yang didukung media tersebut.

Bila merujuk pemikiran Lippman, diyakini bahwa media massa mengantar dan mengarahkan khalayak untuk mengetahui peristiwa-peristiwa yang dianggap penting dan perlu diketahui khalayak. Serta melalui media pula dapat diketahui peristiwa meski kahalayak tidak ada di lokasi peristiwa. Sebab itulah media menjadi sarana efektif bagi penyampaian informasi politik. Kedua media besar tersebut tidak lagi menjamin kepentingan publik. Tanggung jawabnya sebagai kontrol sosial serta sarana menambah wawasan musnah demi kekuasaan politik. Sebagai petarung, media memiliki target pembentukan opini publik, baik yang diharapkan para politisi itu sendiri maupun redaksi. Justru pembentukan opini publik inilah yang menjadi tujuan utama aktor politik (dalam Pilpres 2014) dan media partisannya.

Dengan demikian pada konstruksi informasi yang disebarkan oleh kedua media secara tersurat ingin menyam- 
paikan fakta-fakta seputar isu pelanggaran HAM kepada publik tapi pada saat yang bersamaan secara tersirat juga memperlihatkan perang terbuka antara pendukung capres-cawapres. Publik disuguhkan dengan berbagai nilai-nilai, ideologi, jargon capres-cawapres. Namun ada yang menarik dari data yang diperoleh, vivanews.com memuat foto Prabowo dan Wiranto yang saling berpegangan tangan. Ada indikasi bahwa vivanews.com dibawah komando Aburizal Bakrie masih ada upaya untuk mendinginkan suasana. Wiranto yang menyerang kubu Prabowo dibalas dengan sedikit keteduhan melalui foto dua mantan Jenderal yang saat sedang bersitegang.

Bila bertitik tolak dari teori konstruksi sosial Berger dan Luckmann, maka redaksi dan jurnalis vivanews.com dan mediaindonesia.com memuat semua peristiwa yang terkait capres dan cawapres tidak perlu diragukan kebenaran atas semua ucapan-prilaku kubu Prabowo dan Jokowi. Nilai berita ini dalam terminologi Berger dan Luckmann telah menjadi realitas objektif tersendiri (objectification). Redaksi harus menerimanya sebagai hal yang alami.

Media, dalam bangunan konstruksionisme, menghadirkan pada kita sebuah jendela untuk melihat dunia. Melalui berita, tidak hanya kita belajar untuk mengenali diri kita sendiri dan bangsa lain, akan tetapi orang-orang dari bangsa lain tersebut juga belajar mengenai diri mereka sendiri dan bangsa kita melalui media (dalam Tuchman, 1999).

Dalam persoalan ini, dengan merujuk pada teori konstruksi sosial, maka ideologi masing, masing capres dan cawapres merupakan realitas obyektif. Sementara realitas simbolik dipahami sebagai ekspresi realitas obyektif dalam bentuk lambang komunikasi bisa berupa teks, visual diam mapun bergerak serta suara. Sedangkan realitas subyektif ialah dalam konteks ini ada pada media yang mengkosntruksinya melewati proses internalisasi. Media melalui sifat publikasinya menjadikan realitas subjektif untuk modal berinteraksi dalam struktur sosial. Pada kesempatan ini realitas subjektif berpotensi menjadi realitas objektif yang baru. Begitu seterusnya proses dialektik ini terjadi secara simultan. Redaksi vivanews.com dan mediaindonesia.com memberitakan isu HAM capres-cawapresnya di ruang publik dan melakukan proses dialektis tersebut melalui tahapan simultan.

Diawali dengan proses eksternalisasi, dalam hal ini manusia (khalayak) melakukan eksternalisasi yang terjadi sejak awal, karena menurut pandangan kosntruksi sosial, manusia dilahirkan belum selesai. Untuk menjadi manusia, ia harus mengalami perkembangan kepribadian dan perolehan budaya (Berger dan Luckmann, 1990:5-6). Keadaan manusia yang belum selesai pada saat dilahirkan, membuat dirinya tidak terspesialisasi dari struktur instinktualnya, atau dunianya tidak terprogram. Dunia manusia adalah dunia yang dibentuk (dikonstruksi) oleh aktivitas manusia sendiri; ia harus membentuk dunianya sendiri dalam hubungannya dengan dunia (Berger dan Luckmann, 1990:6-7). Pada persoalan ini, khalayak sebagai manusia telah membentuk (membingkai) dunianya sendiri, hal yang sama dilakukannya pada capres-cawapres. Sementara pada redaksi, tahapan eksternalisasi bisa dipahami saat membentuk (membingkai) peristiwa apapun yang terkait capres-cawapres.

Tahapan objektifikasi. Semua aktivitas manusia yang terjadi dalam eksternalisasi, menurut Berger dan Luckmann (1990:75-76), dapat mengalami proses pembiasaan (habitualisasi) yang kemudian mengalami pelembagaan (institusionalisasi). Lembaga-lembaga juga mengendalikan perilaku manusia dengan menciptakan pola-pola perilaku. 
Pola-pola inilah yang kemudian mengontrol yang melekat pada pelembagaan. Proses eksternalisasi pada khalayak mengalami bias terkait dengan pembingkaian mengenai capre-cawapres versinya. Dalam pembiasan ini khalayak terus melakukan eksternalisasi dan lamalama akan mengalami pelembagaan dalam dirinya. Pelembagaan inilah yang dikenal dengan fase objektifikasi Sementara pada redaksi, proses eksternalisasi yang dilakukannya bersinggungan dengan kepentingan pemilik, kebijakan redaksi bahkan kepentingan sang reporter itu sendiri. Disinilah akan tercipta pola-pola dalam pengemasan berita. Termasuk berita mengenai capres-cawapres yang dibuat oleh vivanews.com serta mediaindonesia.com.

Fase internalisasi, adalah suatu pemahaman atau penafsiran individu secara langsung atas realitas objektif sebagai pengungkapan makna. Berger dan Luckmann (1990:87) menyatakan, dalam internalisasi, individu mengidentifikasikan diri dengan berbagai lembaga sosial atau organisasi sosial dimana individu menjadi anggotanya. Pada khalayak, momen ini terjadi saat ia menafsirkan berita capres-cawapres pada vivanews.com dan mediaindonesia.com dengan referensi politiknya serta kecenderungan afiliasi politik yang ada pada dirinya. Sementara proses internalisasi vivanews.com dan mediaindonesia.com, terjadi manakalan redaksi mencoba mengemas peristiwa menjadi berita melalui referensi politik dan afiliasi politik redaksi yang bersangkutan. Diingat bersama bahwa pemilik viva group (vivanews.com) adalah ketua Golkar yang saat pilpres mendukung capres-cawapres nomor satu. Sementara mediaindonesia.com berafiliasi politik sesuai dengan kebijakan partai Nasdem yang berpihak pada Surya Paloh yang juga pemilik Media Group (mediaindonesia.com).
Dengan demikian, mencermati kontruksi yang dilakukan oleh kedua media, baik portal berita vivanews.com dan mediaindonesia.com, keduanya mempunyai beberapa tekanan berbeda. Dalam konteks capres cawapres ini. Mediaindonesia yang dipimpin oleh Surya Paloh sekaligus menjabat ketua partrai Nasdem jelas mendukung Capres- Cawapres Jokowi JK. Meskipun di luar mengklaim media yang netral tapi kenyataanya tidak demikian. Begitu juga yang terjadi dengan vivanews.com dibawah naungan Abu Rizal Bakrie yang juga sekaligus ketua partai Golkar secara nya mendukung capres-cawapres Prabowo-Hatta.

Media dalam operasionalisasinya menghadapi tekanan-tekanan internal (pemilik) dan eksternal (kepentingan politik, ekonomi, dan sosial). Altschull (1984) menyatakan bahwa "konten media berita selalu mencerminkan kepentingan mereka yang mendanai pers" (dalam McQuail, 2010:6) fakta lainnya sebagaimana diungkap Sudibyo (2012:7) media massa tidak jarang hanya melayani kepentingan ekonomi politik kelompok tertentu saja. Hal itu ditandai dengan adanya konsolidasi ekonomi politik media yang ramah pasar dan keputusan politik yang tidak memperkuat posisi media dalam berhadapan dengan negara dan pemodal.

Sejalan dengan hal tersebut, temuan data menunjukkan bagaimana pemegang tampuk pemilik media mempunyai kuasa terhadap media yang dimilikinya. Ini relevan dengan pemikiran Webber dalam artikel Tuchman (1999) yang menyebutkan bahwa berita bukan semata informasi, dan para jurnalis sebaiknya tidak dipandang sebagai sekadar penjaja informasi atau sekandal melainkan sebagai politikus profesional. Bagi Webber, koran dalam hal ini portal berita vivanews.com dan mediaindo- 
nesia.com bukanlah sekadar alat pencari keuntungan para kapitalis seperti di Inggris selama Perang Dunia, melainkan sebuah organisasi politik yang berfungsi sebagai klub politik. Karena itu baginya, berbicara mengenai politik berarti berbicara mengenai politik di dalam masyarakat.

Baik redaksi vivanews.com ataupun mediaindonesia.com pemiliknya terjun langsung dalam kancah politik di Indonesia. Inilah yang menjadi persoalan di ruang publik dan menjadi kajian yang akan tetap hangat di ranah ilmu komunikasi. Pada Pileg maupun pilpres 2014 secara terang-terangan Aburizal Bakrie sebagai pemilik jaringan vivanews dan Surya Paloh sebagai pemilik Media Group menggunakan media sebagai sarana kampanye politik. Pengaruh kekuasaan pemilik media terhadap netralitas berita sangat kentara. Implikasinya isi berita komersial dalam group terentu cenderung bersifat homogen. Publik pun akan kesulitan mencari referensi karena informasi bersumber dari group media yang dimiliki orang yang sama.

Dalam tinjauan lain, kegiatan media massa dengan aktifitas pemberitaan peristiwa politik tidak bisa dilihat sekadar "tugas jurnalis" tapi menyiratkan adanya ikatan atas dasar suatu kepentingan ekonomi, politik, ataupun ideologis (dalam Hamad, 2002) . Inilah sebabnya dalam dinamika pemberitaan Pilpres 2014 banyak media yang dikuasai oleh pemimpin partai menjadi petarung yang saling serang lawan poltiknya melalui media miliknya. Meski tidak sama persis tapi pada prinsipnya era ini pernah dialami oleh Uni Soviet zaman dahulu, saat Media menjadi corong partai. Sebenarnya ini ironis karena sebuah kemunduran telah terjadi ditengah prinsip demokrasi yang tengah dijadikan landasan bangsa ini dalam mencari presiden melalui pilpres 2014.
Melalui konstruksi berita yang dibuat media mau tidak mau khalayak sulit bahkan tidak memiliki pilihan untuk mencari referensi pilihan berita, terlebih kedua perusahaan media tersebut masuk kategori media berita terbesar di Indonesia. Tiap kali masyarakat mengakses kedua group media itu, saat itu juga isinya hanya calon presiden nomor satu atau calon presiden nomor dua. Beritanya membaguskan-baguskan jagoannya dan membuka aib lawannya atau bahkan mungkin memfitnahnya. Lepas semua nilai-nilai etika jurnalistik, tanggung jawab media, bahkan dari aspek etika politik serta pendidikan politik pun sirna. Publik hanya mendapat kesadaran palsu (Marx dalam Little John: 2008:331).

Dalam perspektif Marxian media berpotensi menyebarkan ideologi dominan. Ideologi dominan inilah yang diasumsikan mempunyai potensi untuk menguatkan hegemoni kekuasaan para pemilik media komersial. Biasanya tekanan pemilik media tidak jauh dari kepentingan ekonomi, politik dan ideologi tersebut. Tekanan dari aspek ekonomi untuk mengembalikan investasinya. Tekanan yang datang dari aspek politik dan ideologi untuk membangun kelanggengan kekuasaan. Semakin kuatnya tekanan dari pemilik media, semakin sulit politik keredaksian media bersikap netral, untuk mempertahankan idepedensinya di hadapan khalayak pemirsanya. Kondisi inilah yang melanda melanda media komersial di Indonesia.

Pengesampingan etika pers, etika politik dan idealisme normatif media sangat mungkin terjadi manakala konstruksi realitas didorong kuat oleh hasrat serta motif politik tertentu. Dalam situasi politik yang panas, seharusnya media mampu menjadi peneduh dan pelindung ketenangan publik. Di tengahtengah pertarungan politik yang semakin runcing. Pers dibutuhkan sebagai faktor pereda dengan senantiasa mengingatkan 
semua pihak tentang pentingnya kedewasaan, kesantunan, respek, dan perilaku bertanggung jawab dalam proses berdemokrasi.

\section{E. KESIMPULAN DAN SARAN}

Saat ini media massa di Indonesia kerap meninggalkan tanggung jawab sosial dan etisnya dalam pemberitaan. Ruang publik tidak lagi menjadi atmosfer pencerahan bagi masyarakat. Justru masyarakatlah yang jadi korban polusinya. Karena dihujani dengan informasi yang simpang siur. Informasi yang saling serang dengan gunakan media terjadi. Berbagai kepentingan yang ada pada media massa turut berkontribusi dalam menciptakan polusi informasi di ruang publik. Media cenderung lebih banyak berfungsi pragmatis untuk kepentingan pemilik media yang kebetulan juga merupakan kekuatan ekonomi dan politik. Jika pun tidak, kekuatan tersebut datang dari luar media itu karena faktor finansial yang melibatkan konglomerasi dan bisnis.

Penguatan masyarakat dalam melakukan pembacaan terhadap informasi yang disajikan media massa merupakan salah satu hal yang bisa dilakukan. Gerakan literasi media dalam dimensi politik perlu dikembangkan secara terus menerus, sehingga akan meningkatkan kapasitas masyarakat dalam melakukan penyaringan informasi. Literasi media bisa saja dilakukan melalui Forum Group Discussion (FGD) di tatanan masyarakat. Elemen sivitas akademik yang ada dikampus bisa jadi pilihan dijadikan sarana untuk melakukan literasi media pada masyarakat.
Dari sisi akademis, perlu dilakukan studi terkait penggunaan analisis bingkai pada topik lain untuk memperkaya khasanah pengetahuan mahasiswa pemerhati komunikasi massa tentang persoalan ideologi media. Pendekatan ekonomi politik media dalam paradigma kritis sangat direkomendasikan memperkaya pemahaman tentang persoalan ideologi media.

Penggunaan pendekatan analisis framing atau bingkai sangat ditekankan untuk memperkaya contoh-contoh metodologis serta sebagai alat untuk analisis teks secara kualitatif. Selain itu pada tatanan riset komunikasi, analisa framing bukanlah satu-satunya model untuk menjawab persoalan tentang arah politik media maupun ideologi seperti halnya kasus ini. Pendekatan kritis dengan varianya bisa dijadikan pilihan.

Sementara pada tatanan praktis, pemilihan bingkai konflik untuk mengkerangkakan sebuah peristiwa hendaknya dilakukan dengan cermat tanpa membuat media terjebak pada sikap provokatif yang bisa menyulut konflik horisontal lebih lanjut. Isu tentang HAM dalam kontestasi pemilu bisa dilakukan dengan pendekatan kritis ekonomi politik media. Selain itu pendekatan Agenda Setting media juga dapat dilakukan untuk membahas isu yang sama. Pemilihan bingkai konflik untuk mengkerangkakan sebuah peristiwa bisa dilakukan dengan cermat tanpa membuat media terjebak pada sikap provokatif yang bisa menyulut konflik horisontal lebih lanjut. 


\section{DAFTAR PUSTAKA}

\section{Buku:}

Berger, Peter L. \& Thomas Luckmann. 1990. Tafsir Sosial atas Kenyataan: Risalah tentang Sosiologi Pengetahuan (diterjemahkan dari buku asli The Social Construction of Reality oleh Hasan Basari). Jakarta: LP3ES.

Bungin, Burhan. 2008. Konstruksi Sosial Media Massa. Jakarta: Kencana Prenada Media Group.

Eriyanto. 2002. Analisis FramingKonstruksi, Ideologi, Politik Media. Yogyakarta: LKIS.

Hall, Stuart. 2003. The Whites of Their Eyes: Racist Ideologies and the Media Dalam Gail Dinez and Jean M. Humez (Eds.), Gender, Race, and Class in 21 Media: A Texteader. Thousand Oaks: Sage Publications

Halls, Jonathan. 2012. Rapid Video Development for Trainers. USA: Abella Publishieng Services.

Littlejhon, Stephen W., Foss a. Karen. 2008. Human Communication. Belmonth-USA: Thomson Wadsworth.

McQuail, Dennis. 2010. McQuail's Mass Communication Theory (Buku I). Jakarta: Salemba Humanika

Pamela J Shoemaker dan Stephen D. Reese. 1996. Mediating The Message, New York: Longman Publisher.
Tankard, Jr., James W. 2001. The Empirical Approach to the Study of Media Framing, in Stephen D. Reese et all, Framing Public Live: Perspective on media and our understanding of the social word, Mehwah, NJ: Lawrence Erlbaum Associates.

\section{Artikel dan Jurnal :}

Entman, Robert M. 1993. Framing: Toward Clarification of a Fractured Paradigm. Journal of Communication 43 (4): hlm 51-8. 1999. Paradigma dan Perkembangan Penelitian Komunikasi dalam Jurnal Ikatan Sarjana Komunikasi Indonesia,Vol III. Jakarta: IKSI dan ROSDA, hlm. 39

Goffman, Erving. 1974. Frame Analysis: An Essay on the Organization of Experience. New York: Harper \& Row

Gamson, W. A., \& Modigliani, A. 1989.

Media discourse and public opinion on nuclear power: A constructionist approach. American Journal of Sociology, 137

Pan, Zhongdang, and Kosicki, Gerald M.1993. Framing analysis: an approach to News Discourse. Political Communication 10: hlm $55^{-75}$

Sudibyo, Agus. 2012. Konsolidasi Ekonomi Politik Media. Kompas: hal. 7 
Tuchman, Gaye, 1999. Qualitative Methode in The Study of News, diterjemahkan oleh Yosal Iriantara, Metode Kualitatif dalam Studi Pemberitaan Media, Artikel dalam jurnal Ikatan Sarjana Komunikasi, Vol III

\section{Sumber internet:}

http://www.mediaindonesia.com/hottopic $\angle \mathrm{read} / 1401 /$ Prabowo-Diminta-

Tanggung-Jawab/2014/06/19

(diakses 26 Juni 2014)

http://www.mediaindonesia.com/hottopic $\angle \mathrm{read} / 1454 /$ Prabowo-InisiatorPenculikan/2014/06/20 (diakses 26 Juni 2014)

http://www.mediaindonesia.com/hottopic /read/1563/KPU-Dinilai-AbaikanHAM/2014/06/24 (diakses 26 Juni 2014)

http://politik.news.viva.co.id/news/read/ 514463-tim-sukses-tunjukkan-suratpemberhentian-terhormat-prabowo (diakses 7 Juli 2014)

http://politik.news.viva.co.id/news/read/ 514518-tim--pemberhentianprabowo-tak-terkait-kasuspenculikan (diakses 6 Juli 2014)

http://politik.news.viva.co.id/news/read/ 514518-tim--pemberhentianprabowo-tak-terkait-kasuspenculikan 